\title{
SMART LEARNING MODELS OF CERTIFIED LEGAL TRANSLATORS AND INTERPRETERS IN CHINA
}

\author{
Ming XU, Master of English Language and Literature \\ School of Foreign Languages, China University of Political \\ Science and Law \\ No. 25, Xitucheng Road, Haidian District, Beijing, China \\ 290020833@qq.com
}

\begin{abstract}
Legal translation has played an important part in the contact between different people and countries in the history, and it is playing an even more significant role in the increasingly globalized world nowadays. This study uses case study method and the data analysis tool voyant to explore smart learning models of certified legal translators and interpreters that they are supposed to grasp. Through the analysis of the guiding case No. 75 of The Supreme People's Court of The People's Republic of China, the graphs show that the legal translator possesses some good competences, though there are some defects in the translation that fail to exhibit the integration of all the presupposed legal translational competences completely. The results find that the prerequisites about knowledge of comparative laws, legal languages and forensic linguistics are the external framework of smart learning models; and the legal translational language competence, legal translational knowledge structures, legal translational strategic competence and context of situation are the internal model. The whole model is multi-componential, interactive, dynamic and developed.
\end{abstract}


Key words: smart learning model; legal translation; language competence; knowledge structures; strategic competence; context of situation

\title{
ZHŌNGGUÓ SHÌGÉ FǍLÛ̉ FĀNYÌZHĚ DE ZHÌHUÌ XUÉXÍ MÓSHÌ.
}

Zhāiyào: Lìshǐ shàng, fãlǜ fānyì zài wéixì bùtóng mínzú hé guójiā de jiāowăng zhōng bàn yăn zhuó zhòngyào juésè, zài dāngjīn rìyì quánqiú huà de shìjiè zhōng gèng fā hū zhuó zhòngyào zuòyòng. Běn yánjiū căiyòng ànlì yánjiū fāngfã hé shùjù fēnxī gōngjù, tànsuǒ shì gé fălü yì zhě yīnggāi zhăngwò de fălü fānyì nénglì de zhìhuì xuéxí móshì. Tōngguò duì zhōnghuá rénmín gònghéguó zuìgāo rénmín fãyuàn dì 75 hào zhǐdăo xìng ànlì de fềnxī, túbiăo xiănshì cǐ fâlü yì zhě jùyǒu yīdìng de nénglì, dàn fānyì zhōng cúnzài yīxiē quēxiàn, wèi néng zhănxiàn chū yù shè de quánbù fălü fānyì nénglì. Jiéguǒ fāxiàn, zhăngwò bǐjiào fã zhīshì, fãlǜ yǔyán zhīshì hé fãlǜ yǔyán xué zhīshì shì xiānjué tiáojiàn, jí wàibù kuàngjià; fãlü fānyì yǔyán nénglì, fãlü fānyì zhīshì jiégòu, fãlü fānyì cèlüè nénglì jí qíngjǐng yǔ jìng shì qí nèibù móshì. Zhěnggè móshì chéngfèn fùhé, xiānghù jiāohù, dòngtài fāzhăn.

Guānjiàn cí: Zhìhuì xuéxí móshì; fãlü fānyì; yǔyán nénglì; zhīshì jiégòu; cèlüè nénglì; yǔ jìng

\section{MODELE INTELIGENTNEGO UCZENIA SIE CERTYFIKOWNYCH TŁUMACZY PISEMNYCH I USTNYCH W CHINACH}

\begin{abstract}
Abstrakt: Tłumaczenie prawnicze odegrało ważną rolę w kontaktach między różnymi ludźmi i krajami w przeszłości, a obecnie odgrywa jeszcze większą rolę w coraz bardziej zglobalizowanym świecie. W badaniu wykorzystano studium przypadku oraz narzędzie do analizy danych inteligentnych modeli kształcenia certyfikowanych tłumaczy prawnych. Dzięki przeprowadzonej analizie sprawy nr 75 Najwyższego Sądu Ludowego Chińskiej Republiki Ludowej, wykresy pokazują, że tłumacz prawniczy posiada pewne kompetencje, chociaż istnieją pewne wady w tłumaczeniu, które nie wykazują integracji wszystkich kompetencji translacyjnych. Wyniki pokazują, że wstępne wymagania dotyczące znajomości prawa w aspekcie porównawczym, języków prawnych i językoznawstwa sądowego stanowią zewnętrzną strukturę modeli inteligentnego uczenia się, a wewnętrznym modelem są kompetencje językowe w zakresie tłumaczeń ustnych, prawne struktury translacyjne, kompetencje strategiczne $\mathrm{w}$ zakresie tłumaczenia prawnego oraz kontekst sytuacyjny. Cały model jest wieloelementowy, interaktywny, dynamiczny i rozbudowany.
\end{abstract}

Słowa kluczowe: inteligentny model uczenia się; tłumaczenie prawne; kompetencje językowe; struktury wiedzy; kompetencje strategiczne; kontekst sytuacyjny 


\section{Comparative Legilinguistics 36/2018}

\section{Introduction}

Recently, law has become the guarantee for countries in the globalized world with so many bilateral documents to sign. Due to different languages between different countries, legal translation has also played a significant role in the bilateral communication. However, the problems about what legal translation competences the legal translators are supposed to grasp, and how they explore and obtain legal translation competences, are still waiting to be discussed and solved. Obviously, based on the phenomenon, the research question is that what legal translation competences a translator or interpreter should process. The research will use case study method, or actually take an example to exhibit Chinese-English translation in a legal text, aiming to explore and discuss the smart learning models of certified legal translators and interpreters. Therefore, the smart learning models of translation and interpretation are regarded as the research object. The guiding case No. 75 of The Supreme People's Court of The People's Republic of China is China Biodiversity Conservation and Green Development Foundation v. Ningxia Ruitai Science and Technology Co., Ltd. (Case about public interest litigation against environmental pollution). The text is issued on December 28, 2016 as deliberated and adopted by the Judicial Committee of The Supreme People's Court. This case is selected according to the topic of environmental protection and its social effects, but its content was not read by the author of this paper before truly studying. In other words, the author of this paper knows nothing about the legal translational factors in this text before the following study.

In China, many scholars have made some researches on the legal translation. For instance, Xiong Demi (2011: 128) in his article On the Special Principles of Legal Translation holds that abiding by the general principle of translation, legal translation shows particularities mainly displaced from four perspectives, namely, professionalization, rigorousness, accuracy and equivalency. Du Jinbang (2005: 11) holds that legal exchange comprises a series of components, one of which is legal translation that is of great importance. There are a number of basic principles of legal exchange, among which the linguistic ones have direct implications for legal translation. Besides, appropriateness is one of the objectives always pursued by translators and interpreters. The combination of legal exchange principles and the ap- 
propriateness of legal translation can enable translators and interpreters to manage the translation process from both macro and micro points of view.

One of the creative and innovative points of this paper is the present research gap in this field that there is seldom study combining the theories with specific cases. Therefore, the first innovative point in this paper is the case study method. The specific case provides legal translators and interpreters with an example to translate and interpret. Secondly, there are a few uses of tool to analyze data in the present researches about legal translation and interpretation. Thus, the second creative point is the use of data analysis tool voyant.

\section{Legal translation competence, performance and proficiency}

\section{Legal translation competence and performance}

In general linguistics, the Aspects of the Theory of Syntax written by Chomsky discussed two concepts: competence and performance. A language user's underlying knowledge about the system of rule is called his linguistic competence (Chomsky, 1965: 3). In other words, competence refers to the ideal user's knowledge of the rules of his language. According to the general linguistic theory, from the literal interpretation, legal translation competence refers to the ideal legal translator's knowledge of the rules of legal translation. More specifically, legal translation competence is an ability to transcript different legal languages by an ideal legal translator. In contrast with competence, performance refers to the actual use of language in concrete situations (Chomsky, 1965: 3). Legal translation performance refers to the actual realization of the ideal legal translator's knowledge of the rules of legal translation in some context. 


\section{Legal translation proficiency}

In contrast with competence and performance, language proficiency has been used in the context of language testing to knowledge, competence or ability in the use of language, irrespective of how, where or under what conditions it has been acquired. Legal translation proficiency refers to the ability to use legal translation competence to perform legal translation tasks in a specified context for intercultural and inter-lingual communication. Roughly speaking, legal translation proficiency concerns more on the context than competence and performance. Similar to the perlocutionary comparing with locutionary and illocutionary, legal translation proficiency integrate the competence, act and result of legal translation.

Smart learning models of legal translation and interpretation

\section{External framework of legal translation competence}

It is certainly that a proper legal translator must grasp some knowledge and skills. Knowledge about law is of the superior position. It is worth noting that here the law is not only the law in one county, but also the law in at least two countries, that is, the comparative law. However, mastering the bilateral laws is just the first step to become a proper legal translator. Today, as in general translation, greater attention is devoted to the cultural aspects of legal translation, which is now regarded as a "transcultural venture" (Varady 2006: 4) in which the translator's task is to achieve cross-cultural transfer (Sandrini 1999: 9-43).

During the past three decades or so, many linguists and social scientists have turned their attention to legal language. There is no doubt that legal language is decidedly peculiar and often hard to understand, especially from the perspective of the lay public. Because legal language differs from ordinary language, it is also interpreted differently (Tiersma 1999: 1-3). Firstly, legal translation and interpre- 
tation is based on the semantic meaning of technical terms, which have a number of dimensions of meanings, that is, denotation and connotation. These ranges are from what concept or concepts the word denotes and what class of entities it can refer to through the connotations and other kinds of personal association (Durant \& Leung 2016: 27). Secondly, legal translation and interpretation attaches great importance on the pragmatic meanings of phrases and sentences. Some pragmatic knowledge is necessary for translators and interpreters to translate and interpret the meaning of texts, as pragmatic theories (e.g. relevance theory) show how discourse interpretation proceeds in part through contextual inference. When the translators and interpreters stand in pragmatic contexts, the pragmatic factors include: the other words around them (co-text); previous instances of the same word elsewhere in the same discourse; the situation in which they are used; and background knowledge likely to be drawn on by a translator or an interpreter. Therefore, as for the translators and interpreters, they are supposed to seek the intended meaning of discourse. Thirdly, legal translation and interpretation places less importance on the speaker's actual meaning when there would have to be more than one plausible sentence meaning. One reason is plain meaning rule, and another is collective authorship. Although the plain meaning rule has been stated that if a document is plain or unambiguous, as determined sole from the language contained in the "four corners" of the document, a judge cannot refer to any outside ("extrinsic") evidence to decide what it means (Tiersma, 1999: 126). The rule has the practical effect of focusing on court's attention on the meaning of words and sentences, rather than on the speaker's intention, even though that intention is legally what should decide the issue. Recently, Justice Scalia of the United States Supreme Court has championed an approach called textualism, which is actually the renew of the plain meaning rule. However, there is an extensive debate in American courts on when, and to what extent, judges should consider legislative intention (the speaker's meaning) when translating and interpreting statutes.

Since legal translation is about language, it is related to linguistics. One cannot make legal translation in any setting or system without first understanding significant and sufficient aspects of phonetics, phonology, morphology, syntax, semantics, pragmatics and then without being willing to apply forensic linguistics. The term forensic linguistics is hotly debated. For some, it denotes only the work of those who provide expert evidence on language for police investi- 
gations or court hearings. For others, the term has a wider meaning which extends to examining courtrooms, particularly criminal ones, by analyzing talk from lawyers and witness. Finally, increasingly the term is coming to have a wider application to denote research on all areas of legal activity from the language of legislation through police stations and even into prisons and out into the worlds of consumers, families and corporations (Rock 2011: 139).

It is can be seen that comparative law, legal language and forensic linguistics are the three prerequisites for legal translation. The competence of these three prerequisites can be regarded as the external framework of smart learning models.

\section{Internal model of legal translation competence}

Internal model of legal translation competence has several characteristics. Firstly, any kind of model is composed of some elements in various ways, whether they are simple or complex, coordinated or hierarchical. The internal model of legal translation competence, based on legal translation proficiency, consists of several components. Secondly, due to different characteristics of different legal translators, the proportion that internal components occupy changes flexibly according to different situation. In other words, internal proportions interact with each other. Thirdly, the interactivity of components initiate a dynamic process of the whole model. In a nutshell, the internal model is multi-componential, interactive and dynamic.

Translation proficiency is thus further described as consisting of three sets of variables interacting with one another in the context of situation (Cao 2007: 40): (1) translational language competence; (2) translational knowledge structures; and (3) translational strategic competence. 


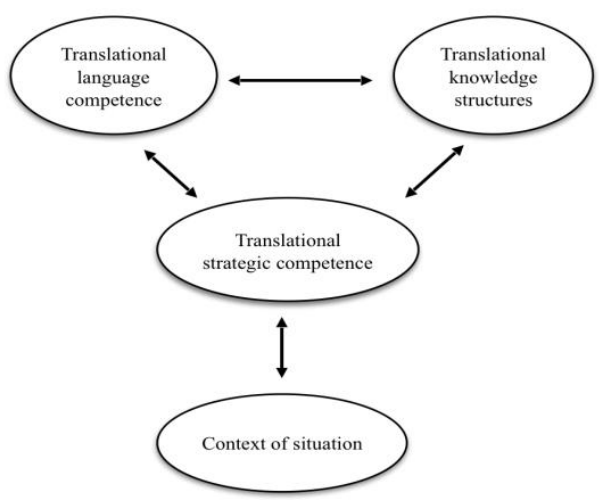

Figure 1: A Model of Translation Competence source: Cao 1996

Translation can be divided into general, specialist and literary translation. Here, Deborah Cao (1996: 78) is mainly based on general translation. Legal translation can be regarded as the specialist translation area or technical translation area, as it possesses numerous technical terms, complex sentence structure, peculiar legal rhetoric and stylistics, formal and ritualistic language. Generally speaking, legal translation is supposed to be in a special and separated field. Herein, the writer have revised the original model translational language competence by adding the "legal" context or situation. The new model of legal translation competence is the following:

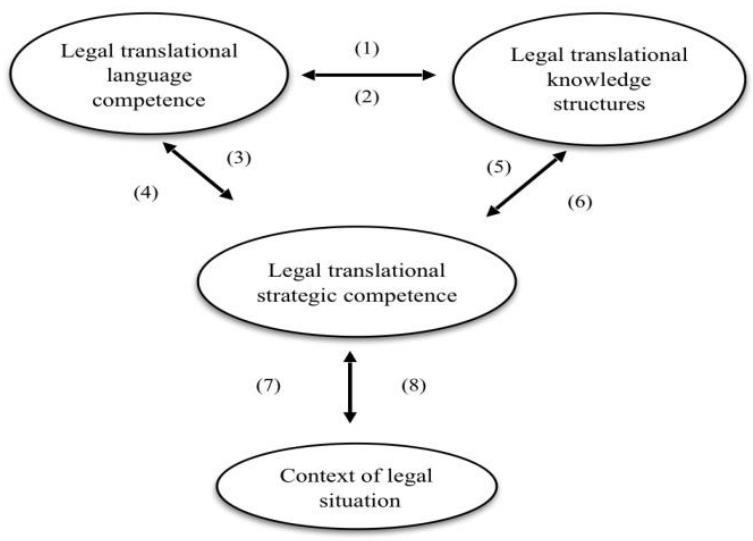

Figure 2: A Model of Legal Translation Competence (revised model) 
In the whole internal interactivity, each component interacts with its adjacent one. Herein, the writer apply a set of antonyms "excellent" and "terrible" to illustrate the two opposite states. In the process (1) and (2), the "excellent" legal translational language competence can promote the grasp of legal translational knowledge structures, and the "terrible" legal translational language competence may impede it, and vice versa. In process (3) and (4), the "excellent" legal translational language competence can promote a better choice about legal translational strategies, and the "terrible" legal translational language competence may lead to a wrong choice about it, and vice versa. In process (5) and (6), "excellently" grasping legal translational knowledge structures is propitious to the choice of legal translational strategies, and "terribly" grasping legal translational knowledge structures goes against the choice of it, and vice versa. In the process (7) and (8), the "excellent" legal translational strategic competence can make the context of legal situation towards a better direction, and "terrible" legal translational strategic competence counts against for the context.

The exploration of internal framework of legal translation competence

\section{The exploration of legal translational language competence}

Legal translational language competence relates to the ability of dealing with source language (SL) and target language (TL) during the process of legal communication. There is no doubt that language competence is the prerequisite of the whole legal translation competence. In the current model, translational language competence comprises a set of specific components in both the SL and TL that are activated and utilized in the translation act of intercultural and interlingual communication (Cao 2007: 42). Based on

Bachman's account of monolingual communicative language use, translational language competence is defined as including: (1) organizational competence; (2) pragmatic competence. The specific components are as followed. 


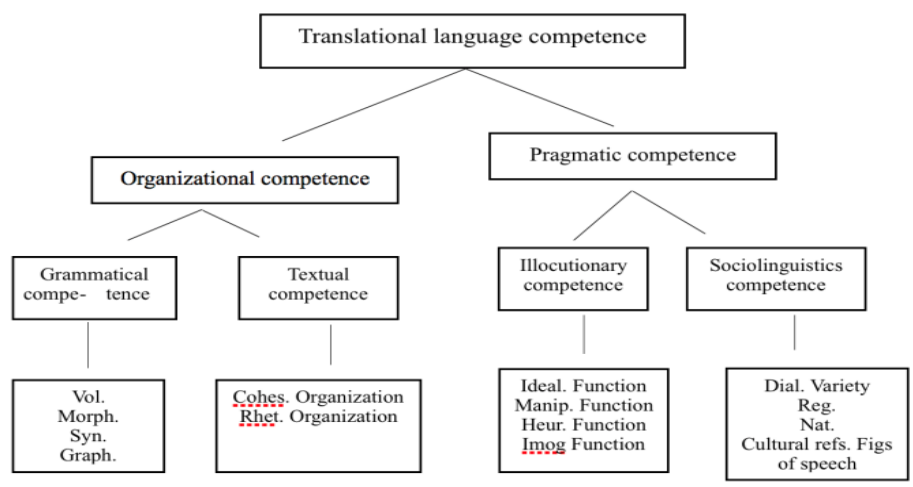

Figure 3: A Model of Translational Language Competence

source: Cao 1996

The relationships between elements are as above. What is worthy to mention is that there are three related concepts: locutionary, illocutionary and perlocutionary in general linguistics. Saying something is to do something, and the act performed is known as an illocutionary act. Illocutionary competence herein is related to the illocutionary force of target language produced by legal translator, which requires them to produce target languages that are of meaningful functions. Sociolinguistics as a field is extremely wide-ranging and includes a multitude of models, methods and theoretical framework. Briefly, it studies the relation between language and society, that is, how social factors influence the structure and use of language. Dealing, as it does, with language use in social contexts, research in the area of sociolinguistics concerns itself primarily with how language is actually used by speakers: how it varies, how it changes, how meaning is signaled and interpreted in social interaction (Llamas 2011: 501).

Based on the original components, the author of this paper has revised and added some new components to the model. Set the context in the legal situation, and then add the "discourse analysis competence" and "intercultural communication competence". Discourse analysis can be defined as the use and development of theories and methods, which elicits how this meaning and coherence is achieved. Legal translator or interpreter is expected to have a correct discourse analysis in order to produce accurate target language. Legal culture is the essence of a country that has been condensed and precipitated in the long river of history. Legal culture is conveyed through translation and translation is the embodiment of legal culture. Since ancient 
times, historical traditions, value orientation, ways of thinking and customs have determined the legal terms, documents and systems in the process of exchanges, conflicts and integrations, which in turn has significant influences on legal translation. Therefore, intercultural communication competence is of vital importance for legal translators and interpreters. The revised model is as followed.

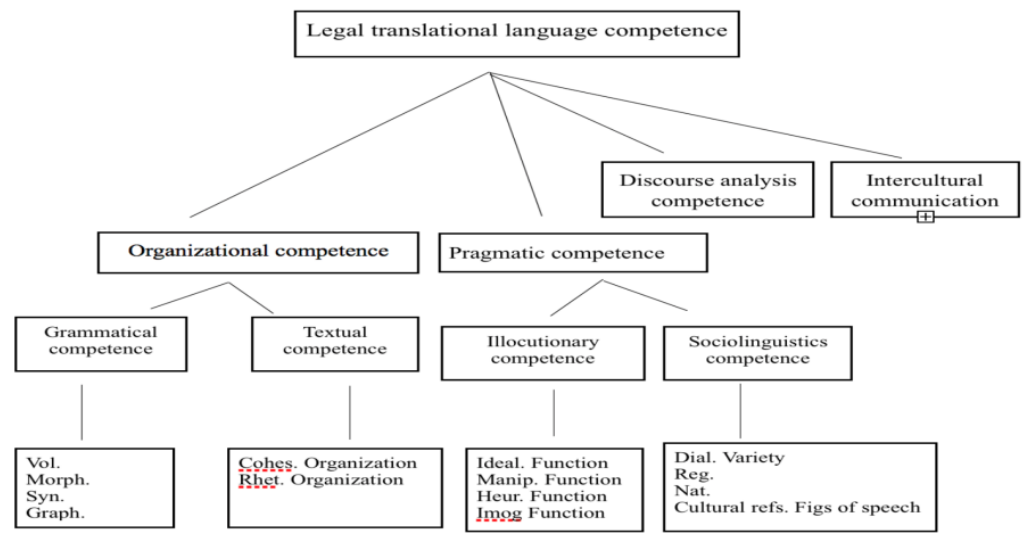

Figure 4: A Model of Legal Translational Language Competence (revised model)

\section{The exploration of legal translational knowledge structure}

Within the present model, translational knowledge structures are defined as the knowledge that is essential to achieve inter-lingual and intercultural communication in translation (Cao 2007: 44). Just as the point that translation can be divided into general, specialist and literary translation, translational knowledge structures are also divided into general, specialist and literary knowledge. General knowledge refers to the knowledge about the world. Literary knowledge includes knowledge in such fields: the film, lyric works, cultural history and literary studies. Specialist knowledge is the subject knowledge that includes technical knowledge in a specialist field. Just as legal translation belongs to the specialist translation, legal translational knowledge structure belongs to the specialist knowledge structure. Legal translational knowledge structure is the knowledge of propositions of law in a narrow sense and the knowledge of legal culture in a broad sense, 
including legal system, legal order, legal institutions, history and practices and practitioners (Tolonen 2004: 1180-1181). The basic legal knowledge about numerous technical terms, complex sentence structure, peculiar legal rhetoric and stylistics, formal and ritualistic language belongs to the narrow sense.

Legal translational structure knowledge is composed of extensive sub-structures, which is dimensional, interactive and dynamic. These sub-structures have two dimensions from the macro and micro points of view, such as technical terms, legal rhetoric or legal history and legal systems. Legal translational structure knowledge is available and acquired by oneself and/ or with the help of others by education and/ or experience.

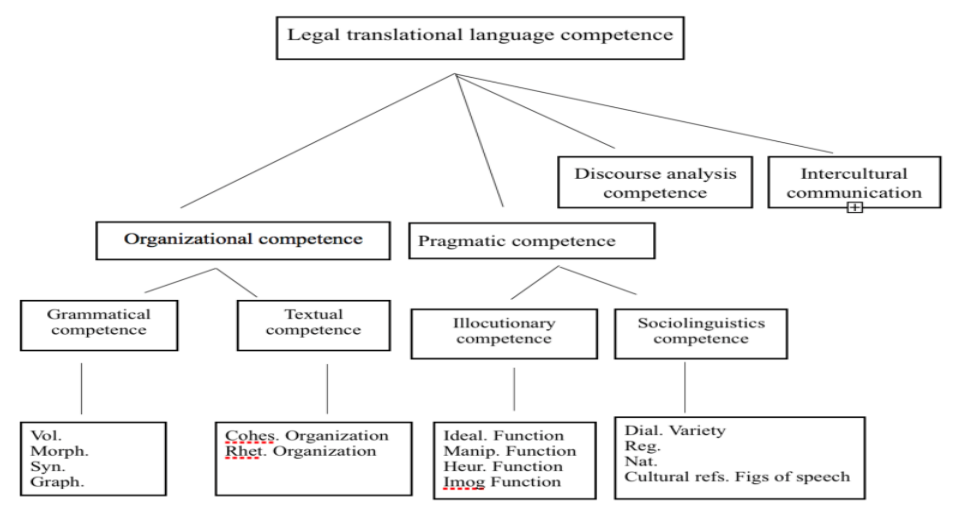

Figure 4: A Model of Legal Translational Language Competence (revised model)

\section{The exploration of legal translational strategic competence}

Translational strategic competence is used to describe the inherent mental ability in the translation task when a translator carries out an operation on a text and enacts language and knowledge competence for communicative purposes in translation (Cao 2007: 48). Legal translational strategic competence is used to describe the inherent mental ability of legal translators applied in legal translation tasks to achieve successful legal communication. It comprises some skills that are demanded during legal translation process. Written translation and 
interpretation are hereby supposed to be distinguished due to the different skills they possess separately. Written translation skills, such as repetition, amplification, omission, conversion, inversion, division, negation, change of the voices (Guo 2010: 78). Interpretation skills includes ear-voice span (EVS), syntactic linearity skills.

Translational strategic competence also includes psychological mechanism that is related to the cognitive linguistics. Cognitive linguistics is based on human experiences of the world and the way they perceive and conceptualize the world. Translational strategic competence concerns on the process when the legal translator receives source languages and how he/ she makes a mental activity to create target language. In a nutshell, it is a complex mental and psychological process.

The example of the smart learning models in the guiding case No. 75

\section{The translation phenomenon in terminological level}

The Chinese-English translation in this judicial document illustrates the external framework and internal framework of legal translation and interpretation. In the Guiding Case No. 75: China Biodiversity Conservation and Green Development Foundation v. Ningxia Ruitai Science and Technology Co., Ltd. (Case about public interest litigation against environmental pollution), according to the data analysis of Voyant, the key words of this judicial document are as followed: 


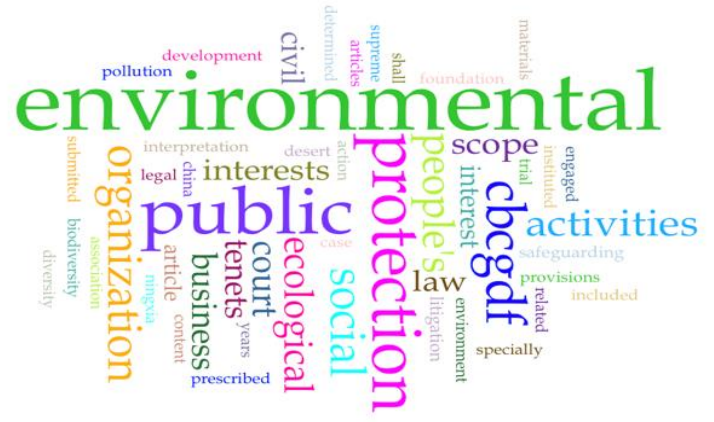

\begin{tabular}{|c|c|c|c|c|}
\hline 田 & $\square$ & 1 & environmental & 71 \\
\hline 田 & $\square$ & 2 & public & 48 \\
\hline$\boxplus$ & $\square$ & 3 & protection & 44 \\
\hline$\boxplus$ & $\square$ & 4 & cbcgdf & 30 \\
\hline$\boxplus$ & $\square$ & 5 & social & 27 \\
\hline$\boxplus$ & $\square$ & 6 & organization & 26 \\
\hline 田 & $\square$ & 7 & activities & 24 \\
\hline 田 & $\square$ & 8 & people's & 22 \\
\hline 田 & $\square$ & 9 & ecological & 21 \\
\hline 田 & $\square$ & 10 & court & 20 \\
\hline 田 & $\square$ & 11 & business & 18 \\
\hline 田 & $\square$ & 12 & civil & 18 \\
\hline
\end{tabular}

Obviously, the key words show the main contents of this judicial document, respectively corresponding to the Chinese texts, as well as the Keywords list in the English texts.

In the Guiding Case No. 75 of The Supreme People's Court of The People's Republic of China, the highest frequency of legal archaisms is hereinafter, reaching to 4 times, according to the data analysis tool Voyant.

\begin{tabular}{|c|c|c|c|c|}
\hline & Document & Left & Term & Right \\
\hline 田 & 1) Labo... & Environmental Civil Public Interest Litigati... & he... & referred to as the "Interpretation \\
\hline 田 & 1) Labo... & Conservation and Green Development Fo... & he... & referred to as the "CBCGDF \\
\hline$\boxplus$ & 1) Labo... & Science and Technology Co., Ltd. ( & he... & referred to as "Ruitai Company \\
\hline$\boxplus$ & 1) Labo... & the People's Republic of China ( & he... & referred to as the "Environmental \\
\hline
\end{tabular}

However, in this judicial document, the result finds that only the word hereinafter is used in high frequency while no other legal archaism is used. The choice of vocabularies can exhibit the legal language competence and legal knowledge structure of legal translators or interpreters. 


\section{The translation phenomenon in phrasal level}

The legal language has the function of persuasion, argumentation or demonstration. It is necessary to use complex technical terms to make difference from daily language. The legal language competence, legal knowledge structure and legal strategic competence of translation or interpretation can be integrated and showed on the phrasal level. Some phrases consist of short and easy-understanding words while transmitting technical meanings, such as, the trial of first instance, trial of second instance, In the effective in this judicial document. Some expressions combine several technical terms together to achieve an accurate effect, such as dismiss the appeal, affirm the original ruling.

\section{The translation phenomenon in syntax level}

Generally speaking, the length of legal sentence is longer than common sentence. Just as the data analysis on this translational judicial document showed, average words per sentence reaches to 45.4 , much longer than that of other fields. The main reason is that legal sentence consists of different sentence patterns and be embedded with participles, adverbial modifiers, clauses. The different sentence patterns require translators and interpreters of outstanding legal strategic competence, besides the translational language competence and legal knowledge structural competence, as well as acquainting the context of situation.

\footnotetext{
国 Summary Documents 团 Phrases

This corpus has 1 document with 2,450 total words and 519 unique word forms. Created now.

Vocabulary Density: 0.212

Average Words Per Sentence: 45.4

Most frequent words in the corpus: environmental (71); public (48); protection (44); cbcgdf (30); social (27)
}

Therefore, on the one hand, the transformation of legal language is based on the knowledge of different legal systems, comparative laws and forensic linguistics from the external framework. On the other hand, it contains the legal translational language competence, 
legal translational knowledge structures, legal translational strategic competence and context of situation from the internal framework, especially the organizational competence and pragmatic competence

\section{Conclusion}

In the globalized world, legal translation has attracted great attention and become an increasingly focus on the study of law and language. The study has taken the guiding case No. 75 of The Supreme People's Court of The People's Republic of China (China Biodiversity Conservation and Green Development Foundation v. Ningxia Ruitai Science and Technology Co., Ltd. (Case about public interest litigation against environmental pollution)) as an example, applied the data analysis tool voyant to carry out case study. The research graphs exhibit the transformation results of language, showing the good competences of legal translator in a way, though there are some defects in the translation that fail to exhibit the integration of all the presupposed legal translational competences completely, maybe due to the complex technical vocabularies, conjoining vocabularies, and sentence patterns. Even so, this paper has explored and illustrated smart learning models of legal translation competence: the external framework and the internal model. The prerequisites about knowledge of comparative laws, legal languages and forensic linguistics consist of the external framework and the legal translational language competence, legal translational knowledge structures, legal translational strategic competence and context of situation consist of the internal model. The components in each level possess their own components and characteristics. The whole model is multi-componential, interactive, dynamic and developed. In a nutshell, translation is a total act.

Through the concrete analysis on the smart learning models of certified translators and interpreters in a case, this paper provides translators and interpreters with directions and train of thoughts to learn and improve their competences. At the same time, it proposes several defects in this translation, and it hopes to produce a few enlightenments on the translation of similar texts. Researches on translation and interpretation of legal language are of significant meanings for promoting the accuracy of legal language, strengthening legal thinking and promoting fairness and justice and improving the juris- 


\section{Comparative Legilinguistics 36/2018}

prudence to the politics of legal language. The smart leaning models of certified legal translators and interpreters are still to be further studied and developed, and some problems that some components are overlapped with each other and that some components may be lost are remained to be discussed in the future.

\section{Bibliography}

Alan, Durant, and Janny HC Leung. 2016. Language and Law. London and. New York: Routledge.

Avram Noam, Chomsky. 1965. Aspects of the Theory of Syntax. Cambridge: MIT Press.

Carmen, Llamas. 2011. Sociolinguistics. In The Routledge Handbook of Applied Linguistics, ed. James Simpson, 501. London and New York: Taylor \& Francis Group.

Deborah, Cao. 2007. Translating Law. Clevedon: Multilingual Matters.

Du, Jinbang. 2005. Legal Exchange Principles and Legal Translation. Journal of Guangdong University of Foreign Studies 4: 11.

Frances, Rock. 2011. Forensic Linguistics. In The Routledge Handbook of Applied Linguistics, ed. James Simpson, 139. London and New York: Taylor \& Francis Group.

Guo, Zhuzhang. 2010. A Practical Course in Translation Between English and Chinese. Wu Han: Wu Han University Press.

Peter M. Tiersma. 1999. Legal language. Chicago and London: The University of Chicago Press.

Salmi, Tolonen. 2004. Legal Linguistic Knowledge and Creating and Interpreting Law in Multilingual Environments. America: Brooklyn Journal of International Law.

Sandrini, Peter. 1999. Translation between Culture and Communication: The Special Case Right. In Translation of Legal Texts, ed. Peter Sandrini, 9-43. Tubingen: Gunter Narr.

Xiong, Demi. 2011. On the Special Principles of Legal Translation. Journal of Southwest University of Political Science and Law 2: 128 .

Varady, Tibor. 2006. Language and Translation in International Commercial Arbitration from the Constitution of the Tribunal through Recognition and Enforcement Proceedings. The Hague: T.M.C. Asser Press; West Nyack, NY: Cambridge University Press. 
Ming XU, Smart learning models of certified legal translators...

The Judicial Committee of the Supreme People's Court. Guiding Case No. 75: China Biodiversity Conservation and Green Development Foundation v. Ningxia Ruitai Science and Technology Co., Ltd. (Case about public interest litigation against environmental pollution). en.pkulaw.cn. http://en.pkulaw.cn/display.aspx ?id=cd0b7b48ac186936bdfb $\&$ lib $=$ case $\&$ SearchKeyword $=\&$ SearchCKeyword $=\quad$ accessed Dec 28, 2016). 